Kodifikasia : Jurnal Penelitian Islam, Vol 15, No. 01 (2021), 1-18

DOI : 10.21154/kodifikasia.v15i1.2757

ISSN : 1907-6371 (Cetak)

ISSN : 2527-9254 (Online)

\title{
DEVELOPING RELIGIOUS VALUES-BASED READING MATERIALS IN INTENSIVE COURSE FOR ISLAMIC HIGHER EDUCATION
}

\author{
Nurul Khasanah*, Maulida Nurhidayati**
}

\begin{abstract}
ABSTRAK:
Penelitian dan pengembangan ini bertujuan untuk mengembangkan bahan bacaan berbasis nilai-nilai agama dalam mata kuliah intensif yang dapat diterapkan secara tepat bagi mahasiswa baru Jurusan Bahasa Inggris InstitutAgama Islam Negeri Ponorogo. Perlu penelitian, merancang bahan bacaan, validasi profesional, merevisi bahan, menguji bahan, dan merevisi bahan semuanya digunakan dalam laporan ini. Mahasiswa diberikan angket dan diwawancarai oleh dosen pengajar dalam melakukan studi kebutuhan. Analisis kebutuhan menunjukkan bahwa sebagian besar mahasiswa setuju untuk mengembangkan bahan bacaan berbasis agama yang sesuai dengan jurusannya dan menyusun bahan sesuai dengan tingkat kesulitannya. . Validasi ahli menunjukkan bahwa materi yang dikembangkan memiliki kekuatan dan keterbatasan tertentu dan bahwa materi yang kurang baik perlu diperbarui. Bukti yang diperoleh dari penggunaan bahan-bahan yang dikembangkan oleh siswa menunjukkan bahwa bahan-bahan tersebut secara efektif membantu siswa dalam mempelajari keterampilan membaca dan komponen bahasa. Bukti pengamatan menunjukkan bahwa siswa terlibat secara positif selama uji coba. Salah satu alasannya adalah bahwa tema yang diperdebatkan menarik dan relevan dengan bidang konten utama siswa. Selanjutnya, kegiatan siswa akan membantu mereka membuka kesadaran mereka tentang topik dan keterampilan bahasa mereka. Berdasarkan hasil uji coba, beberapa perubahan dilakukan pada materi untuk meningkatkan dan akhirnya memenuhi tuntutan siswa.
\end{abstract}

Kata kunci: Bahan Bacaan; Berbasis Agama; Kursus Intensif

\footnotetext{
* State Institute of Islamic Studies Ponorogo, email: khasanah@iainponorogo.ac.id

** State Institute of Islamic Studies Ponorogo, email: nurhidayati@iainponorogo.
} ac.id 


\begin{abstract}
:
This research and development aim to develop religious values-based reading materials in an intensive course that can be appropriately applied for freshmen of English Department of InstitutAgama Islam NegeriPonorogo. Need research, designing reading materials, professional validation, revising the materials, testing out the materials, and revising the materials were all used in this report. Students were given questionnaires and interviewed by a college instructor in conducting a need study. The needs analysis shows that the vast majority of the students agree to develop religious-based reading materials suitable for their department and arrange the materials according to the degree of their difficulty. The expert validation shows that the developed materials have particular strengths and limitations and that the poor ones need to be updated. The evidence obtained from the students' use of the developed materials indicates that they effectively assist students in learning reading skills and language components. Observational evidence suggests that the students were positively engaged during the tryout. One reason is that the themes being debated are engaging and relevant to the students' main content areas. Furthermore, the students' activities will help them unlock their awareness of the topics and their language skills. Based on the trial results, some changes are made to the materials to improve and finally meet the students' demands.
\end{abstract}

Keywords: Reading Materials; Religious-Based; Intensive Course

\title{
BACKGROUND
}

English spread rapidly in any major, for example society, community, business, entertainment, education, and communication. English is one of the international languages. Many people are inspired to study and master English as a result of this. There are two ways to understand and master English: formal and casual. In a formal setting, students learn English at a college, institute, or university under the supervision of a teacher or lecturer. In an informal situation, people acquire English themselves or with families with or without media. Mastering the English language has many benefits. Those are able to get and share information with people around the world; receive a broader opportunity to continue their study in English speaking country. 
In the English language, there are four micro-skills. Speaking, reading, listening, and writing are the four forms of speech. Since the reader acknowledges and obtains the concept or insight from the speaker or the text, listening and reading are referred to as receptive abilities. Since the speaker or writer must create terms, phrases, clauses, or sentences in spoken or written language, speaking and writing are referred to as effective skills. Those skills should be mastered by the students who want to get mastery in English. ${ }^{1}$

Considering the importance of mastering English skills, in 2017 curriculum of IAIN Ponorogo obligates the first semester students of the English Department to take Intensive Course. The intensive course is a course that consists of five subjects in it. They are: listening, reading, speaking, writing, and also grammar. The total credit of the Intensive course is 10 (ten). This is intended to provide English skills to the students in order to they have enough skills to be their capital to continue their study. In teaching every course, the teacher or lecturer should use a suitable textbook to be applied in the teaching and learning process.

Textbooksare also placed as anessential role in the education system to gain the national education goal. The existence of textbooks in the class facilitates the learners to learn the subject comprehensively. Aside from audiovisual media, textbooks are another form of the learning facility. Students should use a manual to develop their language skills to find and complete lessons in class or on their own. "Learners typically have to focus solely on textbooks as a language learning aid," says David Nunan". ${ }^{2}$

1 "The Four Basic Language Skills, Whole Language \&Intergrated Skill Approach in Mainstream University Classrooms in Turkey," Mediterranean Journal of Social Sciences, May 1, 2014, https://doi.org/10.5901/mjss.2014.v5n9p672. \uc0\|u8221\{\}\{\|i\{\}Mediterranean Journal of Social Sciences\}, May 1, 2014, https://doi.org/10.5901/mjss.2014.v5n9p672.”, "plainCitation":"“The Four Basic Language Skills, Whole Language \& Intergrated Skill Approach in Mainstream University Classrooms in Turkey," Mediterranean Journal of Social Sciences, May 1, 2014, https://doi.org/10.5901/mjss.2014.v5n9p672.","noteInde x":3\},"citationItems": [ ‘ "id":77,"uris":["http://zotero.org/users/local/CxmeEAqb/items/ LU8G3RDA"],"uri":["http://zotero.org/users/local/CxmeEAqb/items/LU8G3RDA"]," itemData":\{ "id":77,"type":"article-journal","abstract":"The aim of this research is to determine teaching, evaluation, tendency and assessment levels of English language skills and the consistency among these variables of four basic language skills and higlight the importance of 'integrated language skills' in English at tertiary level in preparation classes with language learners. University level instruction is structured more differently than the first and second cycles and usually builds on previously acquired social and academic knowledge The teaching and assessment levels of four basic language skills have been shown by percentages and frequencies and whether there was a significant difference between the basic language skills of the students was analyzed using the appropriate statistical techniques. Questionnaire about the Learning English (QLE

${ }^{2}$ David Nunan, Second Language Teaching and Learning (Boston: Heinle and Heinle Publisher, 1999). 
The solution to the secularist social education problem within Islam is to bring Islamic values into this issue. Islamic discourse, according to Al-Shaybaniy, includes a variety of educational terms ${ }^{3}$, which can create religious and pious people, devote themselves to God, engage in lifelong learning, and develop one's spirit, feelings, and thoughts in one's body. The creation of a person's ability to perform as God's servant and as God's "Khalifa" is a systematic approach to improve a person's ability to perform as God's servant and as God's "Khalifa" (the representative or agent of God on earth). ${ }^{4}$

According to Al-Shaybaniy, "comprehensive Islamic education" focuses on the general application of Islam. This can be done by combining Islamic knowledge and values, aligning beliefs and traditions, and matching possible religious commitments with "secular affairs." An individual can be educated and trained to learn and uphold the Islamic religion, law, and morality throughout his life through rigorous Islamic education. ${ }^{5}$

${ }^{3}$ MaimunAqshaLubis, Ramlee Mustapha, and Abdullah Awang Lampoh, "Integrated Islamic Education in Brunei Darussalam: Philosophical Issues and Challenges," 2009, 10.some problems surface later, which are thought to impede the implementation of the Integrated Islamic Education in the country. This article aims to examine the extent of the implementation of the Integrated Islamic Education system in Brunei Darussalam and to evaluate whether there is an evident needed to revise the current system. The study found that even though the concept of Integrated Islamic Education is well-received by the society, the teachers are ill-equipped with the effective strategies to inculcate the spirit of the Integrated Islamic Education in their classrooms.","language":"en","pa ge":"10","source":"Zotero","title":"Integrated Islamic Education in Brunei Darussalam: Philosophical Issues and Challenges","author":[\{ “family":"Lubis","given":"Maimun Aq sha” $\},\{$ “family":"Mustapha”,"given”:”Ramlee” $\},\{$ “family":"Lampoh”,"given”:"Abdullah Awang"\}],"issued":\{“date-parts":[["2009”]]\}\}\}],"schema":"https://github.com/citationstyle-language/schema/raw/master/csl-citation.json” $\}$

${ }^{4}$ SeptianDwiCahyo et al., "Needs Analysis of Islamic-Based English Reading Material for the Muhammadiyah Junior High School," International Journal of Evaluation and Research in Education (IJERE) 8, no. 2 (June 1, 2019): 286, https://doi.org/10.11591/ ijere.v8i2.18647.

${ }^{5}$ Lubis, Mustapha, and Lampoh, "Integrated Islamic Education in Brunei Darussalam: Philosophical Issues and Challenges." some problems surface later, which are thought to impede the implementation of the Integrated Islamic Education in the country. This article aims to examine the extent of the implementation of the Integrated Islamic Education system in Brunei Darussalam and to evaluate whether there is an evident needed to revise the current system. The study found that even though the concept of Integrated Islamic Education is well-received by the society, the teachers are ill-equipped with the effective strategies to inculcate the spirit of the Integrated Islamic Education in their classrooms .,"language":"en","page":"10","source":"Zotero","title":"Integrated Islamic Education in Brunei Darussalam: Philosophical Issues and Challenges","author": [\{ "family":"Lubis","g iven":"Maimun Aqsha” $\},\{$ “family":"Mustapha”,"given":"Ramlee” $\},\{$ “family":"Lampoh" ,"given":"Abdullah Awang”\}],"issued":\{“date-parts":[[“2009”]]\}\}\}],"schema”:"https:// github.com/citation-style-language/schema/raw/master/csl-citation.json"\}

Kodifikasia: Jurnal Penelitian Islam, Volume, 15 No. 1 Tahun 2021 
Reading resources for senior students focused on Islamic principles, according to Muhsinin et al., have increased students' reading comprehension. ${ }^{6}$ The syllabus is based on the need to develop reading materials that are distinct from Western society (including Islamic beliefs and culture) and the interests and backgrounds of students in Islamic education. ${ }^{?}$

However, the appropriate textbook that relates to religious values in the Intensive Course in IAIN Ponorogo is not available. The materials in the book, especially reading materials, are not enough for the students to connect to their religion and improve their reading skills. It is getting worse since there is only one exercise in every unit. Based on the explanation above, this paper tries to reveal and develop the religious values-based reading materials in an intensive course to teach first-year students of the English Department of IAIN Ponorogo.

Because this study is about constructing reading materials, the most appropriate design for it is research and development $(R \& D)$. The primary aim of $R \& D$ is to produce practical items that can be used in a school or university rather than to develop or test hypotheses. Teachertraining manuals, instructional resources, collections of behavioral goals, communication materials, and a management framework are all products of the $R \& D$ model.This research was carried out at IAIN Ponorogo. It's on Jalan Pramuka 156 in Ponorogo.

The instruments that used in this research were two kinds. The first was a questionnaire. There werealso two kinds of the questionnaire. The first questionnaire was sent to English Department first-year students. A multiple-choice format was used for the survey. The students were offered a range of options from which to select. The questionnaire was used to collect knowledge about the goal needs and learning criteria. A copy of the second questionnaire was submitted to the specialist. The materials were evaluated using a questionnaire in the form of an agreement-scale.

Using the $R \& D$ approach, experts have introduced a wide range of templates for producing products. The models have similar goals but vary in methods, based on factors such as the school system, the status of learners and students, the learning climate, etc. However, in this report, the materials were created using a Dick and Carey model, which is focused on

${ }^{6}$ MuhsininMuhsinin et al., "The Need to Develop English for Specific Purposes (ESP) Reading Syllabus for Students of Islamic Education Department - Islamic Higher Education Institution," Journal of Foreign Languages, Cultures and Civilizations, 2017, https://doi.org/10.15640/jflcc.v5n1a4.

7 Cahyo et al., "Needs Analysis of Islamic-Based English Reading Material for the Muhammadiyah Junior High School." 
studies on the instructional method and accompanied by elaborating steps, beginning with review and concluding with judgment and revision of the instructional design framework using those procedures. ${ }^{8}$

There are five phases in this model:

1. Conducting Need Analysis

The analyst performed a needs study to gather knowledge about the learners and goal needs. It was also used to gather knowledge for students studying English. The questionnaire was used to perform the study of the needs. There were 17 (seventeen) questions about the students' needs. The questionnaire's findings were informative statistics that defined the students' tendencies on task components (goal, feedback, procedures, teacher's position, learner's role, and setting).

2. Designing the Syllabus

The program was developed based on the needs of the students and the framework's curriculum certification (KKNI). This syllabus describes what students should learn, what resources they should use, and what events they should engage in.

3. Designing the First Draft of the Materials

The materials chosen were created using the syllabus that had previously been created. A draft was the product's name. The produced materials were divided into six units, each with three to six functions. The materials are appropriate for the student's proficiency level and needs.

4. Expert Judgment

After the first draft has been designed, expert judgment is used. In this review, a lecturer with expertise in materials production and skill in assessing materials was chosen as the expert of the developed materials. The second specialist is someone who has a lot of experience creating and providing advice on textbook style. Expert advice was provided in the form of a questionnaire. Any topics are addressed in the queries. Material, presentation, vocabulary, and graphics are the four elements.

5. Writing the Final Draft of the Materials

The outcome of the revisions was used to compose the final draft of the materials after the experts reviewed the materials.

There were three stages applied to product trials, namely expert validation, revision, and tryout of the developed materials. A product trial was conducted after the materials had been developed completely. The purpose of product trial is to see whether the developed materials have met the criteria of an excellent educational product that has been set for developing

${ }^{8}$ Walter Dick, Lou Carey, and James O. Carey, The Systematic Design of Instruction, Eighth edition (Boston: Pearson, 2015).

Kodifikasia: Jurnal Penelitian Islam, Volume, 15 No. 1 Tahun 2021 
reading comprehension materials or not. Whether the developed materials are suitable for the users or not, and whether the developed materials have achieved the objectives or not to solve the learning problems.

1. Expert Validation

Expert validation is the validation of the materials done by experts. According to Peter J. Esseff, reviewing and revising the developed content is known as expert validation. ${ }^{9}$ Validation was carried out at this point by enlisting experts (readers and content experts) to assess and provide feedback on whether the produced material matched the requirements for a successful instructional product that had been established to improve reading comprehension materials. Experts may also assess the developed content using their standards for validation. Concerning expert validation, the decision of who will be the validators of the developed materials is crucial. The experts' determination or validators in the validation process considered several things, such as experience, knowledge, competence, background, attention, and interest of the experts.

2. Revision

The experts' and students' feedback, comments, and suggestions were used to revise the established materials. Data gathered during the expert validation indicates that the developed materials do not meet the requirements provided to improve reading comprehension materials. Data collected from the tryout of the revised materials still indicates difficulties or problems faced by the students in achieving the specified goal. Revision is needed in this report. Thus, correction is made based on the result of expert validation and tryout of the materials.

3. Try Out

When the developed materials fail to meet the requirements during the expert validation period, the materials are updated, and then the revised materials are tested. The aim of a tryout is to determine if the developed content has been fixed or needs to be updated. Furthermore, the tryout aims to gather information about the material's applicability in terms of degree of complexity, usability, efficacy, and attractiveness and identify areas of difficulty or issues that need to be addressed. During the tryout process, students and a fellow professor were given the produced materials to study and were asked to review, draw on, and change the content. Furthermore, during the tryout class, a college professor was assigned to watch the learning and teaching process. Finally, since the

${ }^{9}$ Peter J. Essef, Developing Instructional Material (Columbia: ESF Press, 1980).

Kodifikasia: Jurnal Penelitian Islam, Volume, 15 No. 1 Tahun 2021 
developed materials still do not follow the previously defined standards, it is necessary to revise them again.

In this analysis, the established materials were tested in small groups or with a limited number of participants. Following the revision of the developed materials based on expert views, the next move was to perform a small group or selective tryout with the aims of (1) identifying and omitting the glaring mistakes in the materials such as mistyping, (2) judging the clarity of the content of the materials, (3) identifying the easiness and difficulties in understanding and comprehending the content of the materials, and (4) assessing the materials' efficacy, utility, and aesthetic appeal The participants in the tryout were English Department students at IAIN Ponorogo. As a result, a selection of first-semester English Department students were chosen to be representatives and were included in the tryout process.

\section{REVIEW OF RELATED LITERATURE Reading}

Reading is a two-way conversation between the reader and the author. Students look for and create meaning as they read, depending on both what they bring to the text and what the text brings to them. ${ }^{10}$ Another idea of reading is the act of actively creating and rendering sense from printed material. ${ }^{11}$ Reading entails a lot more than simply arranging words on a page. Reading is naturally basic in understanding the meaning and purpose of sentences, but readers must still grasp those words in context. Furthermore, reading is a strategic method in which readers use hints in the text and their previous experiences to create meaning. ${ }^{12}$ These statements suggest that reading is a method of deriving meaning from written text. The reader communicates with graphic symbols that reflect vocabulary, language competence, and prior knowledge.

People read for several reasons. It is generally known, according to Nutall, that the way people read is affected by their reading ambitions. People read for some purposes, including reality, thoughts, and fun. People read and make links between what they already know and the thoughts on the paper. ${ }^{13}$ When a teacher encourages students to learn, one of the

${ }^{10}$ Hesham Suleiman Alyousef, "Teaching Reading Comprehension to ESL/EFL Learners," n.d., 11.

${ }^{11}$ L.M. Searfoss and J.E Readance, Helping Children Learn to Read (Boston: Allyn and Bacon, 1994).

${ }^{12}$ J.D. Cooper, Literacy: Helping Children Learn to Read (Boston: Houhgton Mifflin Company, 2002).

${ }^{13}$ C. Nutall, Teaching Reading Skills in a Foreign Language (London: Heineman Educational Book Ltd, 2002).

Kodifikasia: Jurnal Penelitian Islam, Volume, 15 No. 1 Tahun 2021 
functions of the teacher is to inform them not only of the benefits of skimming and scanning but also of the value of how they read.

\section{Principles for Teaching Reading Skills: ${ }^{14}$}

1. In an integrated course, include a focus on reading skills

When it comes to learning reading skills, L2 learners who are literate in their native language are often left independently. It is all too easy for teachers to presume that our students will absorb good reading skills. by providing a wide range of reading opportunities, both intensive and comprehensive. In reality, a strategic emphasis on reading skills within lessons that cover other skills may yield significant benefits. Students are reading because virtually all course materials contain the written word, even though their reading is only incidental to other activities. You can inject focal moments in which students attend to reading even in those incidental reading moments.

2. Offer reading on relevant, interesting, motivating topics

Other techniques, such as allowing students to choose their own reading material, can increase their investment. Personal participation in the process is enhanced by carefully sequenced readings and successoriented educational strategies. Readings that assist learners in forming their own identities may also help to strengthen their sense of agency.

3. Balance authenticity and readability in choosing texts

The significance of authentic language should be evident by now. However, the use of so-called simplified texts, has sparked some debate in the classroom. To make an informed decision on this matter, you must first differentiate between (a) simple texts and (b) simplified texts, as well as comprehend the sources of complexity in reading material.

4. Encourage the development of reading strategies

Reading activities should suit one or more reading strategies that have been published. The teacher needs to choose suitable reading strategies based on the students' needs and characteristics.

5. Include both bottom-up and top-down techniques

In the middle of the craze for communicative, authentic language activity in the classroom, teachers often overlook that learners will profit from studying the basics. Make sure you devote enough time in the classroom to concentrating on the fundamentals of written language, as necessary for each level.

${ }^{14} \mathrm{H}$. Douglas Brown and Heekyeong Lee, Teaching by Principles: An Interactive Approach to Language Pedagogy, Fourth edition (White Plains, NY: Pearson Education, 2015). 
6. Follow the "SQ3R" sequences

The SQ3R technique, which consists of five steps, has become an efficient set of processes for approaching a reading text.

7. Design pre-reading, while-reading, and post-reading phases

It's tempting to tell students, particularly at intermediate and advanced levels, "Okay, class, read the next two pages quietly." There was no introduction, no suggestions for what to do while reading, and no thinking about what to do after the quiet reading time. The following three-part framework is a helpful rubric to remember while teaching reading: pre-reading, while-reading, and post-reading.

8. Building ongoing (informal) assessment into the techniques

Because reading comprehension, like listening comprehension, is completely unobservable, being able to correctly evaluate students' understanding and skill development is just as vital in reading as it is in listening.

\section{Teaching Reading in Intensive Course at IAIN Ponorogo}

In general, teaching reading in an Intensive Course aims to pique students' interest in reading, as reading is the most effective way to develop reading skills. Reading, like all subjects, requires a passion for it as well as a lot of practice.

Students receive reading subjects in an intensive course in the first term, according to IAIN Ponorogo's Indonesian Qualification Framework. The Intensive Course consists of five subjects. Listening, writing, speaking, writing, and grammar are the five skills. Each subject is worth two credits. As a result, the Intensive course has a total of 10 credits.

The primary goal of the Reading in Intensive Course at IAIN Ponorogo is to instill a love of reading in the students. Furthermore,by lovingthe reading, the readers will be eager to read many kinds of reading genres.

\section{Materials Development}

Teachers, instructional tools, pupils, tools, and assessment are all essential components of language teaching. Nunan asserts, teaching materials are often the most substantial and observable component of pedagogy. ${ }^{15}$ Teachers aim to write materials that meet the needs of the students, taking into account the importance of the materials.According to Tomlinson, materials development refers to anything that writers, teachers or learners do to provide sources of language input that maximize the likelihood of

${ }^{15}$ David Nunan, Research Method in Language Learning (Cambridge: Cambridge University Press, 1992).

Kodifikasia: Jurnal Penelitian Islam, Volume, 15 No. 1 Tahun 2021 
intake. ${ }^{16}$ The materials can be taken from the internet, newspapers, magazines, songs, literature, and television programs.

\section{Principles of Materials Development}

There are three principles of Materials Development ${ }^{17}$

1. Materials should achieve impact.

Impact means a powerful effect on something. In this case,the material should influence the learners' curiosity and attention.

The criteria of materials that have an impact:
a. Novelty
b. Variety
c. Appealing
d. Interesting material
e. Achievable challenge

2. Materials should put the learner at ease.

The materials should suit with the students' ability. If the materials are written with plenty of white space, have diagrams or images that appeal to their culture or society, and help them understand rather than test them, the students will enjoy doing the exercise.

3. Materials should aid in the development of security in students.

Students' interest in learning is piqued when they have confidence. Students' trust can be built by pushing them beyond their current level of competence in an activity.

\section{Need Analysis}

Need analysis is undoubtedly one of the most critical aspects of preparing and designing a language program. For particular reasons, a need analysis in English acts as a primary source of information that includes linguistic points that students must learn. ${ }^{18}$

It's also done to figure out what students will do with the foreign language in a specific situation and master the target language during the learning process. So that the creator of the English for specific purposes program can comprehend the demands of the student profession and the language used in particular situations based on the student profession.

${ }^{16}$ Brian Tomlinson, Material Development in Language Teaching (Cambridge: Cambridge University Press, 1998).

${ }^{17}$ Tomlinson.

18 “Introduction_to_needs_analysis.Pdf," n.d. 
Target need (what the learner needs to do in the target situation) and learning need (the learner needs to learn) are the two fundamental distinctions in need analysis.

\section{Target needs}

There are three aspects in target needs. Those are: necessities, wants, and lacks.

Necessities are to determine the requirements of the pupils in relation to the contents. Wants are to discover what the kids desire in terms of the content. In addition, lacks are to determine the pupils' lack of understanding of the topic.

2. Learner's needs

There are five components oflearner's needs. They are: input, procedures, teacher's role, learners' role, and setting.

Input is to learn more about the kind of feedback that should be included in the materials. At the same time, procedures will be to determine what pupils should do with the information provided in the assignment. Teacher's role is to learn about the students' perceptions of the teacher's involvement in English acquisition. Learners' role is to discover how students feel about their responsibilities in learning English. The last is setting. Setting is to find out the setting of the materials.

\section{Integrating Religious Values}

In Islamic schools, the primary teaching spirit and characteristic should be Islamic values. Although the core of the 2013 curriculum had improved, it was still far from the concept of integration in terms of application. ${ }^{19}$ School teachers wanted a supplementary book of Islamic themes, according to ZuliantiRohmah's research. It indicated that in order to adapt to the 2013 curriculum the need for integration definition and model should be fulfilled. ${ }^{20}$

In English teaching and learning, Islamic integration can be achieved in two ways: specific and comprehensive integration. Separate classes, such as theology and other Islamic-related topics, teach straightforward integration and Islamic beliefs. It has a drawback in that not all Islamic-based course

${ }^{19}$ Galuh Nur Rohmah, Lina Hanifiyah, and Anita AndriyaNingsih, "Islamic Values Integration In English Lesson At Madrasah Tsanawiyah: Teachers' Beliefs and Practices," Jurnal Bahasa Lingua Scientia 11, no. 1 (June 17, 2019): 93-106, https://doi.org/10.21274/1s.2019.11.1.93-106.

${ }^{20}$ ZuliatiRohmah, "EFL Materials In Madrasah Tsanawiyah: What Do They Really Need?," Teflin Journal 20, no. 1 (August 29, 2015): 104-17, https://doi. org/10.15639/teflinjournal.v20i1/104-117.

Kodifikasia: Jurnal Penelitian Islam, Volume, 15 No. 1 Tahun 2021 
instructors are interculturally qualified, so they only teach about faith without linkingthoughts to students' cultural contexts.

\section{FINDINGS AND DISCUSSION}

The reading materials for the intensive course taught to IAIN Ponorogo first semester students are the commodity that has been created. This study aims to provide students with resources that integrate religious-based materials and are sufficient for their level of skill.

There were a few measures involved in undertaking the analysis. The first step is to assign the questionnaire to the students or perform a need review to assess the learner and aim needs. The second step is to establish an acceptable syllabus based on the results of the need study. The writer wrote the first draft of the syllabus after developing it. The materials were validated to the experts after the first draft was completed. The text, vocabulary, presentation, and graphic were all analyzed by two experts. The experts' suggestions for revisions are the next step. Following the modifications, the researcher gave the materials to the students to carry out. The final step is to revise and test the materials based on the findings of expert validation.

The first step is need analysis. A need analysis aims to gather information about the target needs and learning needs. The data for the need study came from a questionnaire given to IAIN Ponorogo's English Department's first semester students. 123 pupils answered the questions. Target needs are designed to seek the students' need to function effectively and efficiently. There are three parts of target needs. They are: necessities (what learners need to know), lacks (the gap between what learners need to know and what the learners already know), and wants (the learner's need to do something).

Necessity is something that the students intend about the subjects, and this research integrates religious values into the intensive reading course. From the questionnaire, the aim of the students joining intensive courses focused on reading is to get a better understanding of the text that they read. They wanted to be easy to understand any genre of reading text that they read. The students expected that by studying intensive courses focused on reading, they could easily understand their passages. So, the designed materials suited their desire.

Lack is the difficulty faced by the students in studying intensive course focused on reading. From the result of distributing the questionnaire, almost half of the first semester of the English department is in a level of intermediate. It means that they can understand $34-67 \%$ of the passage from the context. They found less difficulty in understanding the passage and in answering the questions. The most significant is that they are generally able 
to deduce the meaning of complicated words from context. The materials should be developed depending on the students' abilities, according to the results of the questionnaire.

Want is the students' intensity related with the subjects. After joining reading course, they wanted to any many kinds of activities related with reading. For example, able to scan the advertisement, able to skim the longer passages, able to identify the topic or topic sentence, able to predict what will be exist in the text from the title or from the picture.

Learning needs refer to what the learners need to do referring to their study. The investigation of the learning needs consist of four aspects: input, procedures, teacher's role, learner's role, and settings.

Input deals with the student's opinion related to the length of the text in a passage and also the amount of the questions every chapter. From the questionnaire can be concluded that the suitable reading passage is around 251 to 350 words. Finding new words in a passage and looking them up in a dictionary to see what they say and parts of speech is the preferred practice for addressing the query. As a result, the produced materials range in length from 251-350 words, with most activities taking the form of word discovery and dictionary research.

Setting refers to classroom arrangement when the subject is taught. The questionnaire can be concluded that the students prefer to study intensive courses focused on reading in a class anddesire to work in groups rather than individually.

Teacher's role related to the student's preference related to the part of the teacher in a classroom. Most of the students prefer a teacher who guides them from the front of the class, approaches them to their seats, and asks them whether they have difficulty.

After performing a need study, the next step is to build a syllabus. The syllabus is developed based on an interpretation of the needs of the learners and the needs of the target audience. The syllabus sets out the materials' structure, order, and organization. All of the findings of the transmitted questionnaire are also covered in the syllabus.

The next move is to create materials based on the syllabus that has been developed. The researcher started working on chapter one of the materials, which consists of a pre-reading exercise accompanied by a passage. The materials that were chosen were Islamic law (syari'ah), Islamic jurisprudence (figh), Islamic belief (aqidah), and morality (akhlaq). There were three types of exercises after the letter. The first was a collection of options. The second kind of query is objective. The final step involves deciding the past of expression as well as building sentences. 
After finishing the first draft of the materials, then the materials were validated to the experts. There are two experts. They are the expert of content and the expert of layout. The experts were given the questionnaire. The questionnaire was in a form of four-scale. The first aspect that the expert evaluates is the content. The mean of the appropriateness of the content was 3.5. the mean between 2.5 to 3.24 is categorized into good. So, there is no additional suggestion from the expert. The next aspect evaluated by the expert is the language. The mean of the language result is 3.25 as the theory said that between 3.25 and 4.00 is categorized into very good. The third aspect evaluated in the questionnaire to the expert is the appropriateness of presentation. This analysis aims to know whether the display is suit with the students' demand. The mean of the result is 3.11, and it is categorized into good category. There are some suggestions from the expert. For example, the task should be ordered from the easiest to the hardest; the activities should be started with the guided to the free one. The last aspect that the expert evaluates is the appropriateness of the graphic. The mean score of the appropriateness of the drawing is 3.22, and it categorized as good. The expert suggests enriching the color and the illustration of the passage to the students easy to understand the passage.

The last step in this research and development is composing a final draft. The final draft is conducting after getting some evaluation or suggestions from the experts related with content, language, presentation, and graphic. The final draft revision is not much since all of the mean scores of the expert judgment is categorized into good. Some suggestions are needed to add the millennial era's content, for example, how to be a youtuber or public influencer; need to be add the interesting and vivid illustration of the materials. The language and exercises should be started with the easiest to the hardest once. The activities should involve the students actively.

\section{CONCLUSION}

This research focuses on creating religious values-based reading resources for students in the English Department at IAIN Ponorogo's Intensive Course to offer an alternate material to deal with the challenges of English learning and teaching at IAIN Ponorogo. The materials are intended to address a current issue at IAIN Ponorogo, namely a shortage of enough materials to help students develop their reading skills. The materials in this thesis were produced using the guidelines proposed by Dick and Carey, beginning with a requires review and concluding with judgment and revision of the content using unique procedures. The resources are in the form of a textbook of reading texts, integrated skill assignments, and language lessons, such as 
16 | Nurul Khasanah, Maulida Nurhidayati

vocabulary and grammar exercises. The material's texts are used in a variety of activities to help students improve their reading, writing, communicating, and listening skills, as well as their vocabulary and grammar knowledge, which leads to language mastery. 


\section{REFERENCES}

Alyousef, Hesham Suleiman. "Teaching Reading Comprehension to ESL/ EFL Learners," n.d., 11.

Brown, H. Douglas, and Heekyeong Lee. Teaching by Principles: An Interactive

Approach to Language Pedagogy. Fourth edition. White Plains, NY: Pearson Education, 2015.

Cahyo, Septian Dwi, Muhammad Rijalul Umam Muslim, Arditya Nur Rahman, and Bambang W Pratolo. "Needs Analysis of Islamic-Based English Reading Material for the Muhammadiyah Junior High School." International Journal of Evaluation and Research in Education (IJERE) 8, no. 2 (June 1, 2019): 286. https://doi.org/10.11591/ijere.v8i2.18647.

Cooper, J.D. Literacy: Helping Children Learn to Read. Boston: Houhgton Mifflin Company, 2002.

Dick, Walter, Lou Carey, and James O. Carey. The Systematic Design of Instruction. Eighth edition. Boston: Pearson, 2015.

Essef, Peter J. Developing Instructional Material. Columbia: ESF Press, 1980. "Introduction_to_needs_analysis.Pdf," n.d.

Lubis, Maimun Aqsha, Ramlee Mustapha, and Abdullah Awang Lampoh. "Integrated Islamic Education in Brunei Darussalam: Philosophical Issues and Challenges," 2009, 10.

Muhsinin, Muhsinin, Mursid Saleh, Dwi Rukmini, and Ahmad Sofwan. "The Need to Develop English for Specific Purposes (ESP) Reading Syllabus for Students of Islamic Education Department - Islamic Higher Education Institution." Journal of Foreign Languages, Cultures and Civilizations, 2017. https://doi.org/10.15640/jflcc.v5n1a4.

Nunan, David. Research Method in Language Learning. Cambridge: Cambridge University Press, 1992.

—. Second Language Teaching and Learning. Boston: Heinle and Heinle Publisher, 1999.

Nutall, C. Teaching Reading Skills in a Foreign Language. London: Heineman Educational Book Ltd, 2002. 
Rohmah, Galuh Nur, Lina Hanifiyah, and Anita Andriya Ningsih. "Islamic Values Integration In English Lesson At Madrasah Tsanawiyah: Teachers' Beliefs And Practices." Jurnal Bahasa Lingua Scientia 11, no. 1 (June 17, 2019): 93-106. https://doi.org/10.21274/1s.2019.11.1.93-106.

Rohmah, Zuliati. "EFL Materials In Madrasah Tsanawiyah: What Do They Really Need?" Teflin Journal 20, no. 1 (August 29, 2015): 104-17. https://doi.org/10.15639/teflinjournal.v20i1/104-117.

Searfoss, L.M., and J.E Readance. Helping Children Learn to Read. Boston: Allyn and Bacon, 1994.

"The Four Basic Language Skills, Whole Language \& Intergrated Skill Approach in Mainstream University Classrooms in Turkey." Mediterranean Journal of Social Sciences, May 1, 2014. https://doi. org/10.5901/mjss.2014.v5n9p672.

Tomlinson, Brian. Material Development in Language Teaching. Cambridge: Cambridge University Press, 1998. 